\title{
Do Disease Epidemics Stimulate or Repress Entrepreneurial Activity?
}

\author{
Aziz N. Berdiev ${ }^{1} \cdot$ James W. Saunoris ${ }^{2}$ \\ Published online: 3 September 2021 \\ (c) EEA 2021
}

\begin{abstract}
This study addresses a unique angle by examining an under looked determinant of entrepreneurship related to disease epidemics. In times of natural disasters, such as disease epidemics, new demands emerge that might promote entrepreneurship. Using data on a large cross section of countries, we empirically test whether and to what extent the incidence and severity of disease epidemics affect the prevalence of entrepreneurship. The results show that both the occurrence and severity of epidemics spur entrepreneurial activity. These results highlight a potentially important role served by entrepreneurs in responding to biological disasters. Our findings withstand a series of robustness checks.
\end{abstract}

Keywords Entrepreneurship · Epidemics · COVID-19 · Economic freedom

JEL Classification L26 · I15 · I18

\section{Introduction}

Researchers and policymakers alike have been interested in better understanding the economic effects of disease epidemics for quite some time (e.g., Becker 1990; Raddatz 2007; Bloom and Mahal 1997). These considerations have gained renewed interest with the advent of the current coronavirus pandemic (e.g., Jordá et al. 2020; Béland et al. 2020; Baldwin and Weder di Mauro 2020; Coibion et al. 2020; Fairlie 2020; Bartik et al. 2020). Adding to the related research on the novel coronavirus pandemic, we investigate the influence of disease epidemics on the prevalence of entrepreneurial activity. Understanding the interrelationship between entrepreneurship and biological disasters could shed light on entrepreneurial motivations

James W. Saunoris

jsaunori@emich.edu

1 Department of Economics, Bryant University, Smithfield, RI, 02917, USA

2 Department of Economics, Eastern Michigan University, Ypsilanti, MI 48197, USA 
especially in unprecedented circumstances such as the current coronavirus pandemic, thereby providing key implications for economic policy.

The prevalence of disease epidemics has been a source of concern for many nations. Reasons for concern are that epidemics dampen output/production (e.g., Raddatz 2007), reduce labor force participation (e.g., Yu et al. 2020), hamper the provision of food assistance (e.g., Cardwell and Ghazalian 2020), and contribute to food insecurity (e.g., Mishra and Rampal 2020). For instance, the shutdown undertaken by governments, in both developed and developing countries alike, to contain/eliminate the severity of the current coronavirus pandemic has halted economic activity across many industries. Of course, while demand for certain goods and services persists, epidemics create additional demand pressures for alternate products (e.g., disinfectants, antibiotics, sanitizers, etc.). These demand pressures could prompt entrepreneurs to unleash their creative energies to satisfy this unique demand.

In this paper, we analyze whether biological disasters create unique opportunities that encourage entrepreneurial activity. While previous research has looked at the relationship between natural disasters and entrepreneurship (Boudreaux et al. 2019), we uniquely examine the impact of biological disasters. Infectious disease epidemics are different from other natural disasters (e.g., geologic, climatic) due to the inherent externality generated by its contagiousness, which create unique uncertainties and challenges. To examine this novel relationship, we use a large sample of nations and consider various epidemics related to infectious diseases. Our focus on disease epidemics, considering both the incidence and severity of epidemics, and their influence on entrepreneurship is a unique aspect of the current paper. Diverse and decentralized knowledge in a market economy makes central planning less effective where entrepreneurs thrive because they can exploit the localized knowledge. Although entrepreneurs play a key role in an economy during times of natural disasters, there is an absence of research that analyzes the nexus between biological disasters and entrepreneurial activity. We thus attempt to answer the following question: does the prevalence of disease epidemics stimulate or repress entrepreneurial activity?

Broadly speaking, entrepreneurs are important drivers of economic activity that promote economic growth and development and raise standards of living. Epidemics could impact various entrepreneurial opportunities, in particular, opportunities for recognition, discovery, and creation (Sarasvathy et al. 2003). For instance, incidence and diffusion of disease epidemics like the COVID-19 pandemic provide crucial opportunities for entrepreneurs to develop creative ways to thwart the spread of the disease through such things as a discovery of a vaccine, as well as to safely satisfy the demand for certain goods and services during a time of need. Of course, the media abounds with examples of the importance of entrepreneurs during times of epidemics and pandemics (https://www.cnbc.com/2020/04/15/hot-spots-of-innov ation-as-a-result-of-coronavirus-pandemic.html). Yet, the crisis brought on by the virus could adversely affect the health of the population (Yu et al. 2020), thereby lowering the available supply of entrepreneurs.

Besides analyzing the frequency of epidemics on entrepreneurship, we also uniquely capture the severity of epidemics related to transmission (the number of people affected by epidemics) and mortality (the number of deaths caused by 
epidemic). In doing so, the results of the analysis expand our knowledge on the nexus between epidemics and entrepreneurship. Using a large sample of countries, the results show that both the occurrence and severity of epidemics are associated with greater entrepreneurship, and these results are robust after accounting for alternate measures of entrepreneurship, additional covariates, simultaneity, outliers, and nonlinearities. Biological disasters classified as epidemics have direct relevance to the current COVID-19 pandemic, and the results of this analysis have important policy implications that help inform policy makers during the current coronavirus pandemic. Given that epidemics encourage entrepreneurship, nations would benefit from allowing the entrepreneurial function of the market economy to work to help prevent, mitigate, and contain the spread of epidemics.

The layout of the remainder of this paper is organized as follows: "Theoretical Considerations and Hypotheses" section discusses the relationship between epidemics and entrepreneurship and outlines a set of testable hypotheses; "Data and Empirical Model" section describes the data and presents the empirical model; "Empirical Results" section discusses the baseline findings and offers a series of robustness checks; the final section summarizes our major findings.

\section{Theoretical Considerations and Hypotheses}

What is the relationship between biological disasters and entrepreneurship? For instance, does the onset of a major biological disaster create opportunities for entrepreneurs to develop new products and processes for limiting the impact of said disasters? Or does the spread and severity of disease epidemics suppress opportunities for entrepreneurs? Understanding why there should be a relationship between epidemics and entrepreneurship can be best explained using the three principles of entrepreneurial opportunities, namely opportunity recognition, opportunity discovery, and opportunity creation (Sarasvathy et al. 2003).

Entrepreneurs are important players in a market economy for their ability and foresight to exploit arbitrage opportunities that serve to match demand and supply, as well as promote innovation (see, for a discussion, Bjørnskov and Foss 2008 and the references therein). The unique "knowledge of the particular circumstances of time and place" empower entrepreneurs to thrive in a time of emergency and uncertainty (Hayek 1945, pp. 521). These qualities enable entrepreneurs to thrive in times of crises posed by disease epidemics. From a Kirznerian perspective (Kirzner 1997), entrepreneurs play a vital role in searching for profit opportunities that serve to best match supply and demand by mobilizing resources to where they are most highly valued given their alternative uses. This is especially important in areas impacted by an epidemic where such things as hospital services may be in short supplye.g., https://www.economist.com/business/2020/03/19/companies-are-scramblingto-build-more-ventilators. Consequently, entrepreneurs recognize these potentials in the market, and, therefore, assemble/activate resources to match demand and supply in unprecedented times such as during epidemics (Sarasvathy et al. 2003).

Another key role served by entrepreneurs, à la Schumpeter, is in stimulating innovation (e.g., Schumpeter 1942). Innovation, in the form of vaccines or creative 
solutions to prevent the spread of diseases, is an obviously important function of entrepreneurs during incidences of epidemics. Arguably, the various restrictions that have been put into effect across many countries to contain the spread of epidemics might make particular goods beyond reach and certain services inaccessible - this provides unique opportunities for innovative entrepreneurs to develop creative solutions to satisfy demand (see, e.g., Ratten (2020) for a discussion on sports entrepreneurship and the current coronavirus pandemic). Amorós et al. (2020, p. 51) argue that "enterprises have adapted the learning curve of their core activities to attend to essential activities during lockdown." Broadly speaking, these prospects enable resourceful entrepreneurs to amplify their existing place in the market (Josty et al. 2020). Thus, the prevalence of disease epidemics offers rare prospects for entrepreneurs to discover and develop new products such as vaccines (Sarasvathy et al. 2003).

The development of new products, such as vaccines, often undergo a lengthy and costly approval process and must adhere to considerable government oversight/regulation. The costly and long delays associated with government bureaucracy, especially in a time of crises, create unique opportunities for "evasive entrepreneurship", which is defined as "profit driven business activity in the market that introduces Schumpeterian technological or organizational innovations in order to evade the existing institutional framework (Elert and Henrekson 2016, p. 100)." For instance, it is possible that governments might not even be able to impose regulations on certain products since these products have yet to be discovered-in this context, these opportunities could promote entrepreneurial entry through such things as developing a formerly undiscovered product that would then have no government oversight (Elert and Henrekson 2016). Furthermore, established businesses may become entrepreneurial by converting their operations to combat epidemics (e.g., switching from producing alcohol to sanitizers, switching from making clothing to face masks). The diffusion of epidemics would nonetheless promote entrepreneurial discovery.

Epidemics may also influence entrepreneurial creation as would-be entrepreneurs respond to disasters by creating novel markets (Sarasvathy et al. 2003; Amorós et al. 2020; D’Adda et al. 2020; Nordhagen et al. 2021). For example, in the current pandemic, entrepreneurs came to the rescue to fight loneliness and other mental health issues related to isolation (https://www.cnbc.com/2020/05/13/entrepreneurs-start ups-are-tackling-coronavirus-isolation-loneliness.html). In general, disease epidemics could influence the relative costs and benefits of starting up a business. Arguably, a more severe epidemic raises the opportunity cost of entrepreneurs' current ventures and encourages them to abandon, pause, or re-tool these endeavors to focus their efforts on the epidemic. This might be especially evident during economic downturns, where the cost-benefit calculation adjusts in favor of bringing products or services to market. ${ }^{1}$ Kelley and Wright (2020, p. 30) argue that "[e]ntrepreneurial thinking becomes more critical than ever during times of global crisis, since

\footnotetext{
${ }^{1}$ For a discussion on business cycles and entrepreneurship, see, e.g., Thurik et al. (2008), Koellinger and Thurik (2012) and Yu et al. (2014).
} 
opportunities emerge out of uncertainty and make way for different business models, new products or services, and innovative practices." All these factors could lead to heightened entrepreneurial creation.

Nevertheless, it is important to note that the diffusion of deadly diseases could suppress entrepreneurial opportunities discussed above, namely curbing opportunities for recognition, discovery, and creation. For instance, the spread and severity of diseases - through high infection rates - might negatively impact the overall health of the general population (Yu et al. 2020), thereby reducing the available supply of entrepreneurs. Empirical studies show, based on cross-country data, that epidemics reduce labor force participation (Yu et al. 2020). Similar evidence was provided using data for the current coronavirus pandemic for the USA (Béland et al. 2020). Some even suggest that the possibility of contracting the virus could discourage entrepreneurial activity - for instance, Yu et al. (2020, p. 2391) argue that the "[f]ear of infection and risk aversion cause workers to drift away from engaging in daily production activities with person-to-person contact." Additionally, Bartik et al. (2020, p. 17662) demonstrate, using survey data for the USA, that "[c]oncerns about employee health" has been a major obstacle for business activity during the coronavirus pandemic.

There can be additional instances when the incidences of epidemics could lower entrepreneurship. Economic crises brought on by epidemics reduce consumption and thus contribute to weaker demand for some goods and services (e.g., Barro et al. 2020; Bartik et al. 2020; Fairlie 2020), which, in turn, could suppress opportunities, and thus reduce the prevalence of entrepreneurship. Furthermore, under extreme circumstances such as the current pandemic, to limit the spread of the virus many governments implemented a near complete shutdown of the economy, through such things as strict curfews and heavy fines, where individuals are not permitted to leave their residence (unless of course the government declared them "essential workers"). In this case, entrepreneurs might not be able to even function, at least in the formal sector of the economy unless they were able to successfully convince the government that their work was essential. Indeed, recent single country studies by Amorós et al. (2020), Bosma and Hart (2020), D'Adda et al. (2020), Fairlie (2020), Guelich and Takahashi (2020), Josty et al. (2020), and Bartik et al. (2020) suggest that business establishments have experienced a decrease in operations during the coronavirus pandemic. ${ }^{2}$

Accordingly, the above discussion suggests that the impact of disease epidemics on entrepreneurial activity is not clear a priori. Instead, this is an empirical question that leads us to formally outline the following testable hypotheses (under the null of no effect):

\footnotetext{
${ }^{2}$ Various studies have recently analyzed the economic effects of the 1918 influenza pandemic, and even focus on a specific nation (e.g., Beach et al. 2020; Barro et al. 2020; Geloso and Pavlik 2020; Basco et al. 2020; Correia et al. 2020; Galletta and Giommoni 2020; Dahl et al. 2020) in order to shed light on the current coronavirus pandemic.
} 
H1a A greater prevalence of epidemics is associated with higher entrepreneurial activity, ceteris paribus.

H1b A greater prevalence of epidemics is associated with lower entrepreneurial activity, ceteris paribus.

Besides studying how the incidence of disease epidemics influence entrepreneurial activity, we also consider the severity of epidemics related to transmission (the number of people affected by epidemics) and mortality (the number of deaths caused by epidemics) and their impact on entrepreneurship. In testing the above hypotheses, we are able to merge two streams of the literature, namely the literature that studies the economic consequences of disease epidemics (e.g., Becker 1990; Raddatz 2007; Jordá et al. 2020; Bloom and Mahal 1997; Barro et al. 2020) and the literature that explores the drivers of entrepreneurial activity (e.g., Bjørnskov and Foss 2008; Saunoris and Sajny 2017; Cebula et al. 2015; Boudreaux et al. 2019; Chambers and Munemo 2019).

In what follows, we describe the data used in the analysis and present the empirical methodology.

\section{Data and Empirical Model}

\section{Data}

The data set is a cross section of around 100 countries averaged from 2000 to 2019 see Table 6 for a list of countries. Although, panel data would be preferred, there are several reasons we use a cross-sectional data set comprised of the unweighted average of the variables. First, the main independent variables, which include the number of people affected and deaths, are reported for each epidemic and not by year. Second, the data set includes several missing observations. Third, the main variables including entrepreneurship and epidemics are likely plagued by measurement error that would be mitigated by averaging. Finally, most of the variation in the main independent variable, epidemics, occurs across countries. For these reasons, we proceed with a cross-sectional dataset. ${ }^{3}$

The variables are collected from highly reputable sources that provide consistency across countries - see Table 1 for variable definitions, sources, and summary statistics. The main variable of interest is a measure of entrepreneurship, that is collected from the global entrepreneurship monitor (GEM) based on data from the Adult Population Survey, which surveys at least 2000 adults on entrepreneurial

\footnotetext{
3 While we focus on the cross-section results, we did, however, estimate equation (1) using panel data based on three-year averages and a two-way fixed effects model. The results showed a positive and statistically significant effect of the number of epidemic incidences on entrepreneurship, whereas the effect of the number affected and number of deaths was somewhat mixed. These results should be interpreted with caution and are available upon request from the authors.
} 


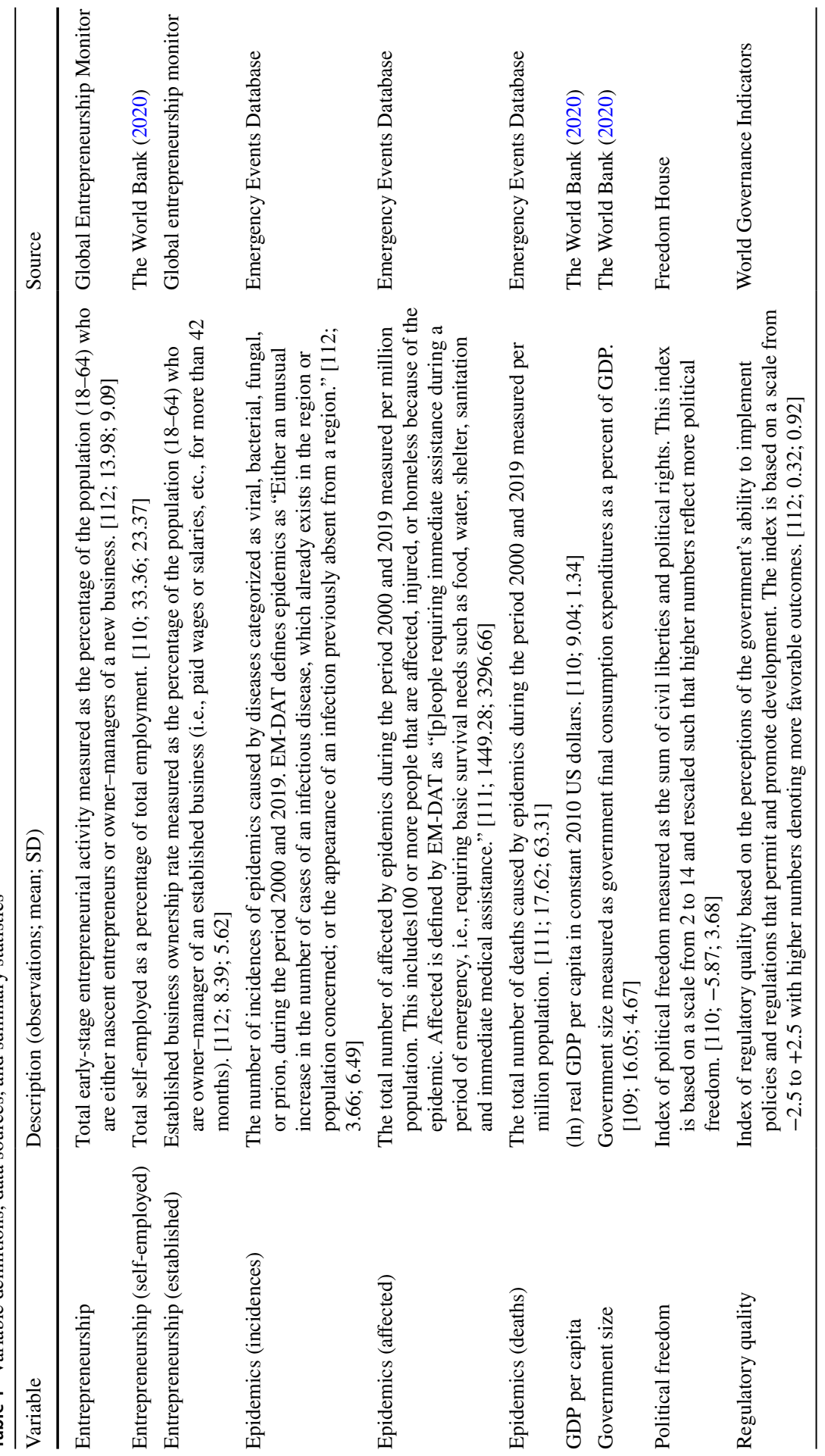

我这 


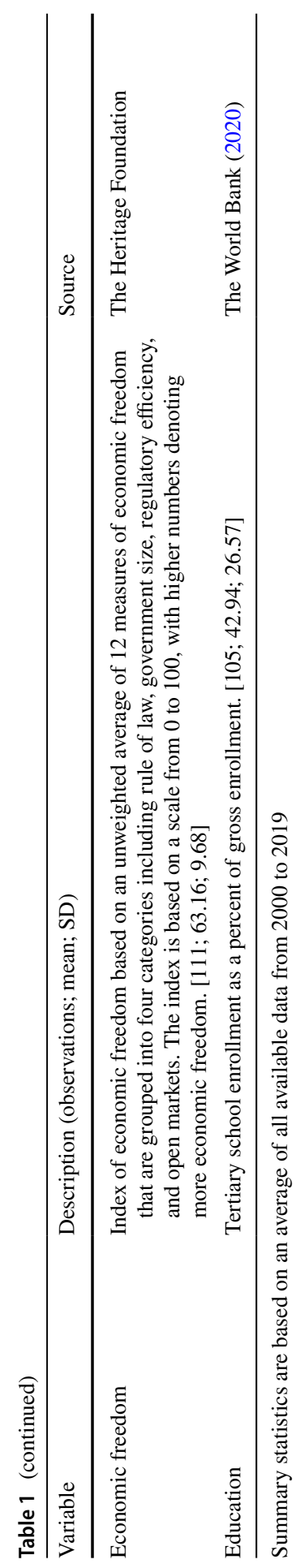


activity. ${ }^{4}$ GEM defines entrepreneurship as "Any attempt at new business or new venture creation, such as self-employment, a new business organization, or the expansion of an existing business, by an individual, a team of individuals, or an established business." ${ }^{5}$ In this paper we use the measure of entrepreneurship labeled "early-stage entrepreneurial activity", which combines "nascent entrepreneurship" (i.e., setting up a new firm) and owner or manager of a new few firm $(<3.5$ years old). Therefore, this measure covers the process of entrepreneurship from conception to firm birth to persistence. This measure of entrepreneurship is calculated as the number of nascent entrepreneurs or new business owners as a percentage of the population aged 18-64. The average rate of entrepreneurship is $14 \%$, with the highest rate of entrepreneurship in Vanuatu (52\%) and the lowest in Suriname (3.6\%).

Our primary interest is the impact of disease epidemics on the prevalence of entrepreneurship. Emergency Events Database (EM-DAT) from the Center for Research on Epidemiology of Disasters (CRED, www.cred.be) compiles information from a variety of sources on natural disasters including geophysical, meteorological, hydrological, climatological, biological, and extra-terrestrial (e.g., disasters caused by asteroids, meteoroids, and comets) dating back to 1900 (see Noy 2009; Kahn 2005; Raddatz 2007 for prior studies that used this database). In this paper, we focus on biological disasters related to epidemics caused by the following diseases: viral, bacterial, parasitic, fungal, and prion. According to EM-DAT a biological hazard is defined as "[a] hazard caused by the exposure to living organisms and their toxic substances (e.g., venom, mold) or vector-borne diseases that they may carry" and they define an epidemic as "[e]ither an unusual increase in the number of cases of an infectious disease, which already exists in the region or population concerned; or the appearance of an infection previously absent from a region (https:// www.emdat.be/Glossary\#letter_d)." According to our data, Cholera makes up the majority of epidemics (39\%) with Dengue in a distant second (8\%), followed by Meningococcal disease in third (5\%). Further, different disease epidemics tend to be somewhat regional specific.

Using these data, we constructed three variables to capture different aspects of epidemics during the period 2000-2019. First, we calculate the number of incidences of epidemics during the period 2000-2019 (Epidemics (incidences)). This measure tells us the frequency of epidemics. Figure 1 illustrates the variation in disease epidemic incidences across countries. Next, we use two measures to capture the severity of epidemics in terms of its transmission and mortality. To capture the transmission of the disease, we calculate the total number of people affected by epidemics (2000-2019) divided by the population in millions (Epidemics (affected)). EM-DAT defines "affected" as "[p]eople requiring immediate assistance during a period of emergency, i.e., requiring basic survival needs such as food, water, shelter, sanitation and immediate medical assistance (https://www.emdat.be/Glossary\# letter_d)." Finally, to capture the mortality of the disease, we calculate the total

\footnotetext{
${ }^{4}$ For more details on the construction of the entrepreneurship variable see https://www.gemconsortium. org/about/wiki.

5 For additional details, see https://www.gemconsortium.org/wiki/1149.
}

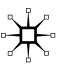




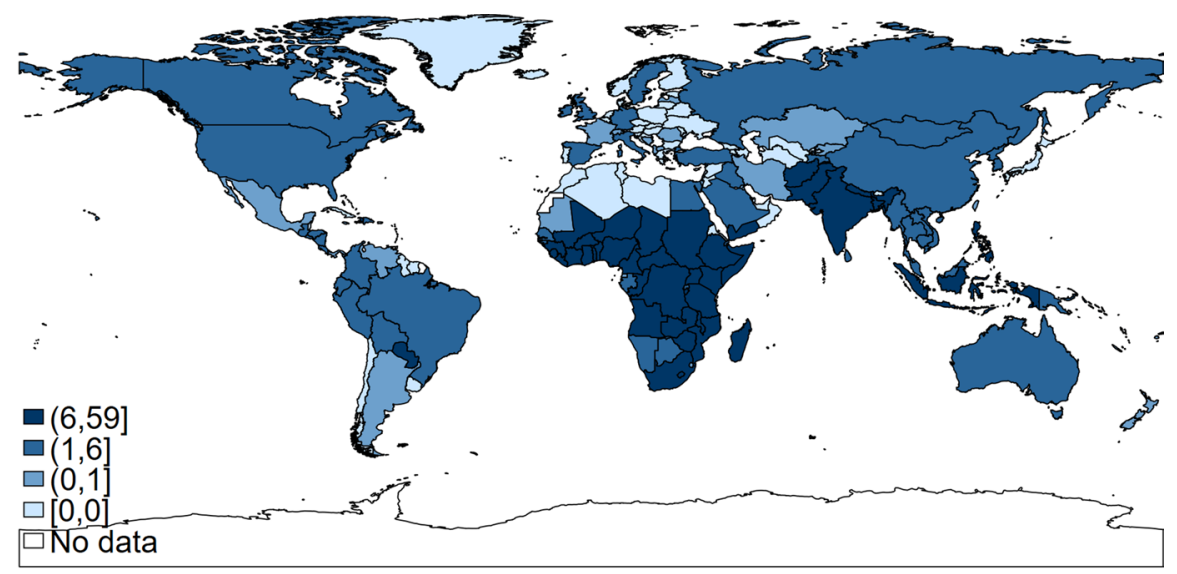

Note: Data based on the number of epidemic incidences from 2000 to 2019 (Epidemic Incidences). Source: www.cred.be and authors' calculations

Fig. 1 The number of disease epidemic incidences from 2000 to 2019

number of deaths caused by epidemics (2000-2019) divided by population in millions (Epidemics (deaths)).

The country with the highest incidence of epidemics is the Democratic Republic of the Congo, whereas the country most affected by epidemics is Burundi, and the country with the most deaths is Liberia. All three measures of epidemics are positively correlated with a correlation coefficient slightly less than 0.5 , which suggests they are capturing somewhat different aspects of epidemics.

Turning to other factors that likely impact the rate of entrepreneurship, we broadly control for economic and political institutions, as well as demographics. Richer countries, in terms of higher (ln) GDP per capita, promote entrepreneurship by offering more opportunities. Alternatively, greater prosperity also means more opportunities for gainful employment that raise the opportunity cost of entrepreneurship, especially those entrepreneurs that are necessity-driven. The impact of the size of government on entrepreneurship is also ambiguous. On the one hand, a larger government may devote more resources to promote entrepreneurship, while on the other hand, larger governments may be more prone to erect barriers (e.g., regulations, taxes and fees, licensing, etc.) that inhibit entrepreneurship.

Countries that are freer, economically, and politically, are more likely to encourage entrepreneurship (Bjørnskov and Foss 2008; Cebula et al. 2015; Saunoris and Sajny 2017). Greater economic freedom translates to, for example, lower taxes and regulations making it easier to start a business and earn a profit. Similarly, greater civil liberties and political rights encourage entrepreneurs to start new businesses given their ability to vote inept and corrupt government officials out of office. Regulations are another important factor in the decision to become an entrepreneur. Regulatory barriers make it difficult for new entrepreneurs to enter the market; however, the quality regulations may prove beneficial to entrepreneurs (Chambers and Munemo 2019). Lastly, we control for education such that greater enrollment in schools, especially at the tertiary level, benefits potential entrepreneurs by providing 
them with the knowledge and skills to navigate the complexities of starting a business; however, this also raises the opportunity cost of being an entrepreneur given their high skills makes them more marketable in the labor market.

\section{Empirical Model}

To test our main hypotheses, we estimated the following model:

$$
\text { Entrepreneurship }_{i}=\beta_{0}+\beta_{1} \text { Epidemics }_{i}^{k}+\gamma^{\prime} X_{i}+\varepsilon_{i}
$$

where $i$ indexes a country. The dependent variable is the total early-stage entrepreneurial rate; the main independent variable is Epidemics, where $k$ indexes the number of incidences of epidemics (Epidemics (incidences)), number of affected per capita (Epidemics (affected)), and number of deaths per capita (Epidemics (deaths)); $X$ is a vector of control variables discussed above and includes GDP per capita, Government size, Political freedom, Economic freedom, Regulatory quality, and Education, and $\varepsilon$ is the random error term with the usual white noise properties.

To estimate Eq. (1), we use OLS. In addition, we report several diagnostic tests including the Breusch-Pagan test for heteroskedasticity under the null hypothesis that the residuals are homoscedastic, and the Ramsey RESET test under the null that there are no omitted variables. The results from the diagnostic tests are reported at the bottom of Table 2. The low $p$ values for the Breusch-Pagan test for heteroskedasticity reject homoskedasticity in favor of heteroskedasticity. To correct for this, we report robust standard errors in parentheses. The rejection of the Ramsey RESET test suggests the omission of possible nonlinearities; thus, we account for possible nonlinearities in "Robustness Check 4: Accounting for Possible Non-linearities" section.

\section{Empirical Results}

\section{Baseline Results}

The baseline results are reported in Table 2. First, we estimate the influence of each epidemic variable on entrepreneurship without any control variables in Models 2.1-2.3. Next, following the extant literature, we include a set of covariates that may impact the relationship between epidemics and entrepreneurship and re-estimate Models 2.1-2.3 and report the results in Models 2.4-2.6. Furthermore, we present the elasticity estimates for the epidemics variables at the bottom of the table.

The coefficients on each of the epidemics variables without the control variables in Models 2.1-2.3 are positive and statistically significant at the 1 percent level, thereby suggesting that a greater prevalence of disease epidemics is associated with more entrepreneurship. In particular, the occurrence and severity of epidemics significantly promotes entrepreneurship, which is consistent with Hypotheses 1a. In terms of economic significance, the elasticity estimates show that a 10 percent increase in epidemic incidences increases the entrepreneurship rate by about 
Table 2 Epidemics and entrepreneurship: baseline models (dependent variable: Entrepreneurship)

\begin{tabular}{|c|c|c|c|c|c|c|}
\hline & $(2.1)$ & $(2.2)$ & $(2.3)$ & $(2.4)$ & $(2.5)$ & $(2.6)$ \\
\hline Epidemics (incidence) & $\begin{array}{l}0.698 * * * \\
(0.129)\end{array}$ & & & $\begin{array}{l}0.394 * * * \\
(0.125)\end{array}$ & & \\
\hline Epidemics (affected) & & $\begin{array}{l}0.001 * * * \\
(0.0004)\end{array}$ & & & $\begin{array}{l}0.001 * \\
(0.0004)\end{array}$ & \\
\hline Epidemics (deaths) & & & $\begin{array}{l}0.057 * * * \\
(0.022)\end{array}$ & & & $\begin{array}{l}0.034 * * \\
(0.015)\end{array}$ \\
\hline GDP per capita & & & & $\begin{array}{l}-0.698 \\
(1.008)\end{array}$ & $\begin{array}{l}-1.213 \\
(1.005)\end{array}$ & $\begin{array}{l}-0.816 \\
(1.105)\end{array}$ \\
\hline Government size & & & & $\begin{array}{l}0.175 \\
(0.173)\end{array}$ & $\begin{array}{l}-0.078 \\
(0.192)\end{array}$ & $\begin{array}{l}-0.171 \\
(0.201)\end{array}$ \\
\hline Political freedom & & & & $\begin{array}{l}0.887 * * * \\
(0.329)\end{array}$ & $\begin{array}{l}0.668 * \\
(0.360)\end{array}$ & $\begin{array}{l}0.848 * * \\
(0.340)\end{array}$ \\
\hline Regulatory quality & & & & $\begin{array}{l}-12.304 * * * \\
(3.877)\end{array}$ & $\begin{array}{l}-8.484^{* *} \\
(4.195)\end{array}$ & $\begin{array}{l}-10.434 * * * \\
(3.949)\end{array}$ \\
\hline Economic freedom & & & & $\begin{array}{l}0.860 * * * \\
(0.244)\end{array}$ & $\begin{array}{l}0.597 * * \\
(0.266)\end{array}$ & $\begin{array}{l}0.715^{* * * *} \\
(0.244)\end{array}$ \\
\hline Education & & & & $\begin{array}{l}-0.070 * * \\
(0.034)\end{array}$ & $\begin{array}{l}-0.074 * \\
(0.037)\end{array}$ & $\begin{array}{l}-0.072 * * \\
(0.036)\end{array}$ \\
\hline \multicolumn{7}{|l|}{ Elasticity } \\
\hline Epidemics (incidence) & $\begin{array}{l}0.183 * * * \\
(0.033)\end{array}$ & & & $\begin{array}{l}0.110 * * * \\
(0.036)\end{array}$ & & \\
\hline Epidemics (affected) & & $\begin{array}{l}0.131 * * * \\
(0.027)\end{array}$ & & & $\begin{array}{l}0.071 * \\
(0.041)\end{array}$ & \\
\hline Epidemics (deaths) & & & $\begin{array}{l}0.071 * * * \\
(0.027)\end{array}$ & & & $\begin{array}{l}0.045 * * \\
(0.021)\end{array}$ \\
\hline Heteroskedasticity test & {$[0.038]$} & {$[0.000]$} & {$[0.016]$} & {$[0.000]$} & {$[0.000]$} & {$[0.000]$} \\
\hline RESET test & {$[0.003]$} & {$[0.000]$} & {$[0.000]$} & {$[0.401]$} & {$[0.000]$} & {$[0.010]$} \\
\hline Observations & 112 & 111 & 111 & 100 & 100 & 100 \\
\hline R-squared & 0.248 & 0.211 & 0.155 & 0.524 & 0.506 & 0.518 \\
\hline
\end{tabular}

See Table 1 for variable details. Robust standard errors are in parentheses, and $p$ values are in brackets Asterisks denote the following significance levels: $* * * p<0.01, * * p<0.05$, and $* p<0.1$

1.8 percent. Regarding the severity of epidemics, the estimated elasticity shows that a 10 percent increase in the number of affected (deaths) caused by epidemics increases the entrepreneurship rate by about $1.3(0.7)$ percent.

When we account for other important factors that have been shown to influence entrepreneurial activity in Models 2.4-2.6 of Table 2, the results continue to illustrate that the coefficients on the epidemics variables are positive and statistically significant at least at the 10 percent level. Although the coefficients are somewhat smaller for Epidemics (incidences) and Epidemics (deaths), they continue to support the main findings that epidemics - frequency and severity—are positively associated 
with entrepreneurship. ${ }^{6}$ Numerically speaking, a 10 percent increase in epidemic incidences increases the entrepreneurship rate by 1.1 percent, whereas a 10 percent increase in the number of affected (deaths) caused by epidemics increases the entrepreneurship rate by $0.7(0.5)$ percent. $^{7}$

Our unique consideration of disease epidemics and their positive and statistically significant impact on entrepreneurial activity shows that epidemics and the emergencies they create, generate opportunities for entrepreneurs to supply goods and services to people in need. Consequently, entrepreneurs, given their unique localized knowledge and foresight, are an important first-responder in the case of biological disasters. This is especially important when the bureaucracy of government constrains it from acting quick enough.

Turning to the control variables, we find that the coefficients on the freedom variables are positive and statistically significant across all models, thus indicating that freedom - both political and economic - plays an important role in promoting entrepreneurship. The results also show that regulatory quality and education enrollment reduce entrepreneurship. ${ }^{8}$ Lastly, it appears that economic development and government size have a limited impact on entrepreneurship. Specifically, the coefficients on economic development and government size are negative (except in Model 2.4, the coefficient on government size is positive), albeit statistically insignificant at conventional levels across all models. Overall, the results for the control variables are broadly consistent with the extant literature.

The following subsections present various robustness checks.

\section{Robustness Check 1: Considering Alternate Measures of Entrepreneurship}

Due to the multidimensional nature of entrepreneurship, we check the robustness of our main results using two alternate measures of entrepreneurship. In Models 3.1-3.3 of Table 3, we use self-employment as a percentage of total employment (Entrepreneurship (self-employ)), and in Models 3.4-3.6 we use the established business ownership rate (Entrepreneurship (established)), which is the percentage of the population aged 18-64 that are owners or managers of an established business.

According to Parker (2018), self-employment and business ownership represent risk-taking activity and thus provides a rationale for using these measures as a proxy

\footnotetext{
${ }^{6}$ After including each of the control variables individually into the regression, the results show that controlling for level of development has the largest impact on the impact of epidemics on entrepreneurship. Conceivably, more prosperous countries with better institutions are better able to combat epidemics and rely less on entrepreneurship.

${ }^{7}$ We also checked the robustness of our results by considering additional control variables including total patents (foreign and domestic) per capita, total current health expenditures (\% of GDP), net official development assistance (\% of GDP), urban population (\% of total population), an index of political stability, and labor force participation rate. These findings continue to support our baseline results such that the coefficients on the epidemic variables were positive and statistically significant.

${ }^{8}$ Interestingly, upon further investigation, we find that the effect of regulatory quality on entrepreneurship is nonlinear and " $U$ " shaped, suggesting that regulatory quality must meet some threshold level before it becomes beneficial to encourage entrepreneurship.
} 
Table 3 Epidemics and entrepreneurship: robustness check 1 (considering alternate measures of entrepreneurship)

\begin{tabular}{|c|c|c|c|c|c|c|}
\hline \multirow[t]{2}{*}{ Dependent variable } & \multicolumn{3}{|c|}{ Entrepreneurship (self-employment) } & \multicolumn{3}{|c|}{ Entrepreneurship (established) } \\
\hline & $(3.1)$ & $(3.2)$ & $(3.3)$ & $(3.4)$ & $(3.5)$ & $(3.6)$ \\
\hline Epidemics (incidence) & $\begin{array}{l}0.917 * * * \\
(0.198)\end{array}$ & & & $\begin{array}{l}0.168 * \\
(0.090)\end{array}$ & & \\
\hline Epidemics (affected) & & $\begin{array}{l}0.001 \\
(0.0006)\end{array}$ & & & $\begin{array}{l}0.0004 * \\
(0.0002)\end{array}$ & \\
\hline Epidemics (deaths) & & & $\begin{array}{l}0.060 * * * \\
(0.017)\end{array}$ & & & $\begin{array}{l}0.017 * * \\
(0.007)\end{array}$ \\
\hline GDP per capita & $\begin{array}{l}-11.686^{* * * *} \\
(1.912)\end{array}$ & $\begin{array}{l}-13.434 * * * \\
(1.957)\end{array}$ & $\begin{array}{l}-12.444 * * * \\
(1.956)\end{array}$ & $\begin{array}{l}-3.117 * * * \\
(0.805)\end{array}$ & $\begin{array}{l}-3.265^{* * *} \\
(0.755)\end{array}$ & $\begin{array}{l}-3.105^{* * *} \\
(0.809)\end{array}$ \\
\hline Government size & $\begin{array}{l}-0.672 * * \\
(0.308)\end{array}$ & $\begin{array}{l}-1.162 * * * \\
(0.326)\end{array}$ & $\begin{array}{l}-1.379 * * * \\
(0.312)\end{array}$ & $\begin{array}{l}-0.058 \\
(0.152)\end{array}$ & $\begin{array}{l}-0.179 \\
(0.144)\end{array}$ & $\begin{array}{l}-0.219 \\
(0.133)\end{array}$ \\
\hline Political freedom & $\begin{array}{l}0.797 \\
(0.500)\end{array}$ & $\begin{array}{l}0.446 \\
(0.529)\end{array}$ & $\begin{array}{l}0.682 \\
(0.518)\end{array}$ & $\begin{array}{l}0.246 \\
(0.235)\end{array}$ & $\begin{array}{l}0.131 \\
(0.246)\end{array}$ & $\begin{array}{l}0.233 \\
(0.239)\end{array}$ \\
\hline Regulatory quality & $\begin{array}{l}1.944 \\
(5.227)\end{array}$ & $\begin{array}{l}8.698 \\
(5.573)\end{array}$ & $\begin{array}{l}6.367 \\
(5.455)\end{array}$ & $\begin{array}{l}1.414 \\
(2.723)\end{array}$ & $\begin{array}{l}3.327 \\
(2.822)\end{array}$ & $\begin{array}{l}2.204 \\
(2.709)\end{array}$ \\
\hline Economic freedom & $\begin{array}{l}-0.027 \\
(0.360)\end{array}$ & $\begin{array}{l}-0.462 \\
(0.408)\end{array}$ & $\begin{array}{l}-0.346 \\
(0.390)\end{array}$ & $\begin{array}{l}0.015 \\
(0.173)\end{array}$ & $\begin{array}{l}-0.121 \\
(0.181)\end{array}$ & $\begin{array}{l}-0.049 \\
(0.170)\end{array}$ \\
\hline Education & $\begin{array}{l}-0.096 \\
(0.072)\end{array}$ & $\begin{array}{l}-0.122 \\
(0.079)\end{array}$ & $\begin{array}{l}-0.110 \\
(0.077)\end{array}$ & $\begin{array}{l}0.026 \\
(0.023)\end{array}$ & $\begin{array}{l}0.027 \\
(0.024)\end{array}$ & $\begin{array}{l}0.026 \\
(0.023)\end{array}$ \\
\hline Observations & 100 & 100 & 100 & 100 & 100 & 100 \\
\hline R-squared & 0.802 & 0.768 & 0.782 & 0.368 & 0.374 & 0.374 \\
\hline
\end{tabular}

See Table 1 for variable details. Robust standard errors are in parentheses

Asterisks denote the following significance levels: $* * * p<0.01, * * p<0.05$, and $* p<0.1$

for entrepreneurship. However, as Parker (2018) points out, these measures may also include individuals that are unlikely to be entrepreneurs or fail to include individuals that are entrepreneurs. For example, self-employment may include individuals that are actual employees, and this measure is also likely to not count nascent entrepreneurs-see Parker (2018) for details on these measures. Nonetheless, these measures are widely used measures of entrepreneurship and provide a readily available measure that can be used a robustness check.

The results show that the coefficients on Epidemics (incidences) and Epidemics (deaths) are both positive and statistically significant, whereas the number of affected by epidemics positively impacts only established businesses. ${ }^{9}$ These results confirm our baseline results across other dimensions of entrepreneurship.

\footnotetext{
9 Conceivably, the positive impact of epidemics on self-employment, in particular, may be explained by the adverse effects of epidemics on the economy and the lack of employment opportunities that force individuals to seek out self-employment as a substitute for employment and to make ends meet.
} 
Consistent with the multidimensional aspects of entrepreneurship, the controls show remarkable differences relative to the baseline models. For instance, the coefficient on GDP per capita is now negative and statistically significant across all models, which is consistent with greater development providing more employment opportunities that may mitigate the need for self-employment-especially among necessity-driven entrepreneurs. The negative and significant effect of log of GDP per capita on entrepreneurship has been noted elsewhere in the literature (see, e.g., Bjørnskov and Foss 2008; Goel and Saunoris 2019). The coefficients on political freedom and economic freedom are now statistically insignificant. Likewise, the coefficient on education is statistically insignificant across all models. In sum, while the determinants of entrepreneurship depend somewhat on the measure of entrepreneurship used, the influence of epidemics consistently shows positive and significant effects on entrepreneurship regardless of the measure used.

\section{Robustness Check 2: Correcting for the Possible Influence of Outliers}

OLS estimates are susceptible to outlying observations, therefore, as an initial screening we computed the Cook's distance for each regression in Table 2. The Cook's distance statistics was then compared to $4 / n$ ( $n$ is the number of observations) to determine potential outliers. Based on this exercise, we found potential outliers and, thus, to ensure outliers are not distorting the OLS estimates, we reestimated the baseline models using robust regression and quantile regression at the median. Robust regression first removes outliers based on a Cook's distance greater than one, then the process is iterative such that weights (derived from Huber weights and biweights) are calculated for each regression, and these updated weights are used in subsequent regressions. The process stops once the maximum change in the weights reaches some threshold level (see Hamilton 1992 for more details). Quantile regression is a regression using the method of minimum absolute deviations where the median is based on the 50th percentile. ${ }^{10}$

After performing robust regression on Eq. (1), the results are reported in Models 4.1-4.3 in Table 4. Interestingly, after accounting for the influence of outliers, the coefficients on the epidemic variables are larger in magnitude and more statistically significant. Similarly, the median regression results, reported in Models 4.4-4.6 in Table 4, show similar effects to the robust regression results, albeit slightly smaller in magnitude. Overall, these results suggest that epidemics are even more important for promoting entrepreneurship than alluded to by the baseline results. The coefficients on the control variables are also largely consistent with the baseline models.

\footnotetext{
10 Additionally, we re-estimated the baseline models after winsorizing (i.e., removing the top 1 th percentile and bottom 99th percentile of observations) the dependent variable, entrepreneurship, and each epidemic variable. The results continue to support the baseline findings.
} 
Table 4 Epidemics and entrepreneurship: robustness check 2 (correcting for the possible influence of outliers)

\begin{tabular}{|c|c|c|c|c|c|c|}
\hline \multirow[t]{2}{*}{ Estimation method: } & \multicolumn{3}{|c|}{ Robust regression } & \multicolumn{3}{|c|}{ Median regression } \\
\hline & $(4.1)$ & $(4.2)$ & $(4.3)$ & $(4.4)$ & $(4.5)$ & $(4.6)$ \\
\hline Epidemics (incidence) & $\begin{array}{l}0.563 * * * \\
(0.101)\end{array}$ & & & $\begin{array}{l}0.510 * * \\
(0.225)\end{array}$ & & \\
\hline Epidemics (affected) & & $\begin{array}{l}0.002 * * * \\
(0.0002)\end{array}$ & & & $\begin{array}{l}0.001 * * \\
(0.0005)\end{array}$ & \\
\hline Epidemics (deaths) & & & $\begin{array}{l}0.088 * * * \\
(0.015)\end{array}$ & & & $\begin{array}{l}0.064 \\
(0.047)\end{array}$ \\
\hline GDP per capita & $\begin{array}{l}-0.916 \\
(0.828)\end{array}$ & $\begin{array}{l}-0.829 \\
(0.741)\end{array}$ & $\begin{array}{l}-0.344 \\
(0.754)\end{array}$ & $\begin{array}{l}-0.290 \\
(1.445)\end{array}$ & $\begin{array}{l}-0.671 \\
(1.353)\end{array}$ & $\begin{array}{l}0.456 \\
(1.360)\end{array}$ \\
\hline Government size & $\begin{array}{l}0.095 \\
(0.150)\end{array}$ & $\begin{array}{l}-0.099 \\
(0.135)\end{array}$ & $\begin{array}{l}-0.200 \\
(0.139)\end{array}$ & $\begin{array}{l}0.116 \\
(0.213)\end{array}$ & $\begin{array}{l}0.014 \\
(0.242)\end{array}$ & $\begin{array}{l}-0.186 \\
(0.202)\end{array}$ \\
\hline Political freedom & $\begin{array}{l}0.532 * * \\
(0.222)\end{array}$ & $\begin{array}{l}0.149 \\
(0.208)\end{array}$ & $\begin{array}{l}0.442 * * \\
(0.203)\end{array}$ & $\begin{array}{l}0.646 * * \\
(0.292)\end{array}$ & $\begin{array}{l}0.350 \\
(0.409)\end{array}$ & $\begin{array}{l}0.645^{* *} \\
(0.308)\end{array}$ \\
\hline Regulatory quality & $\begin{array}{l}-8.103 * * * \\
(2.480)\end{array}$ & $\begin{array}{l}-5.595^{* *} \\
(2.303)\end{array}$ & $\begin{array}{l}-7.235^{* * * *} \\
(2.229)\end{array}$ & $\begin{array}{l}-9.479 * * * \\
(3.022)\end{array}$ & $\begin{array}{l}-7.095^{*} \\
(3.705)\end{array}$ & $\begin{array}{l}-9.455^{* * * *} \\
(3.209)\end{array}$ \\
\hline Economic freedom & $\begin{array}{l}0.609 * * * \\
(0.172)\end{array}$ & $\begin{array}{l}0.483 * * * \\
(0.163)\end{array}$ & $\begin{array}{l}0.508 * * * \\
(0.156)\end{array}$ & $\begin{array}{l}0.686 * * * \\
(0.184)\end{array}$ & $\begin{array}{l}0.521 * * * \\
(0.196)\end{array}$ & $\begin{array}{l}0.547 * * * \\
(0.183)\end{array}$ \\
\hline Education & $\begin{array}{l}-0.028 \\
(0.031)\end{array}$ & $\begin{array}{l}-0.005 \\
(0.029)\end{array}$ & $\begin{array}{l}-0.010 \\
(0.029)\end{array}$ & $\begin{array}{l}-0.030 \\
(0.031)\end{array}$ & $\begin{array}{l}-0.042 \\
(0.034)\end{array}$ & $\begin{array}{l}-0.018 \\
(0.027)\end{array}$ \\
\hline Observations & 100 & 100 & 99 & 100 & 100 & 100 \\
\hline R-squared & 0.590 & 0.619 & 0.565 & 0.339 & 0.326 & 0.331 \\
\hline
\end{tabular}

See Table 1 for variable details. Models 4.1-4.3 are estimated using robust regression; Models 4.4-4.6 are estimated using the median regression

Asterisks denote the following significance levels: $* * * p<0.01, * * p<0.05$, and $* p<0.1$

\section{Robustness Check 3: Accounting for Potential Simultaneity Bias}

The relationship between epidemics and entrepreneurship may be bi-directional; thus, this potential simultaneity may bias the main findings. For instance, entrepreneurs are important for the development of products and processes that mitigate or prevent the spread of diseases. Therefore, to check the robustness of the baseline results to potential endogeneity, we re-estimated the baseline models using two-step efficient GMM and instrumented all three epidemic variables. To instrument each epidemic variable, we considered their spatial lag averaged from 1990 to $1999 .^{11}$ The spatial lag is a weighted average of neighboring countries' epidemic variable. The spatial lag is calculated by pre-multiplying the epidemic variable by an $N \times N(N$ is the number of countries) weight matrix $W$. Each element in the $W$ weight matrix

\footnotetext{
11 Prior research has also considered spatial lags as instruments (see, e.g., Berggren and Nilsson 2015; Bergh and Nilsson 2014).
} 
Table 5 Epidemics and entrepreneurship: robustness checks 3 and 4 (accounting for potential simultaneity and nonlinearities)

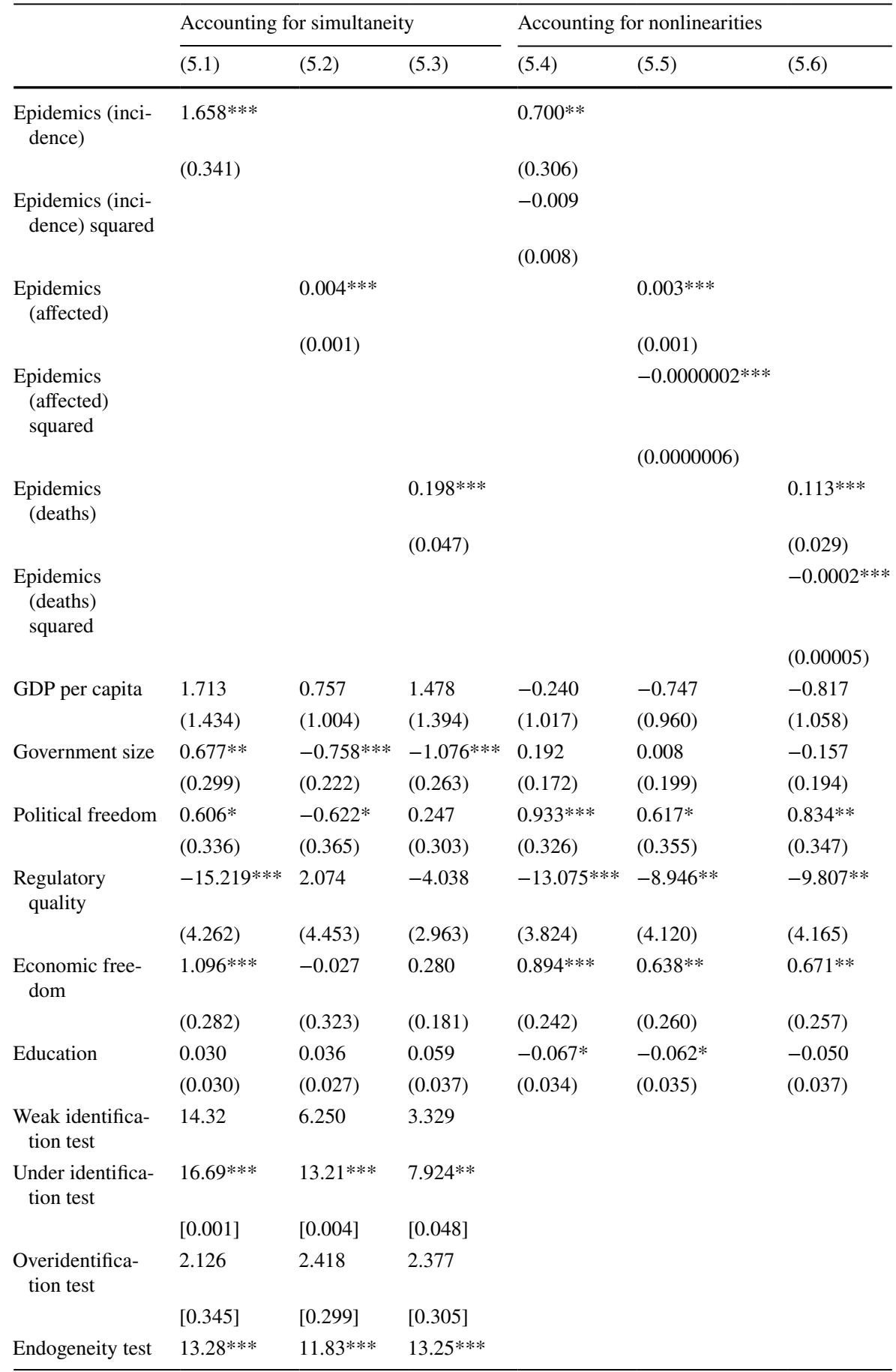


Table 5 (continued)

\begin{tabular}{|c|c|c|c|c|c|c|}
\hline & \multicolumn{3}{|c|}{ Accounting for simultaneity } & \multicolumn{3}{|c|}{ Accounting for nonlinearities } \\
\hline & $(5.1)$ & $(5.2)$ & $(5.3)$ & $(5.4)$ & $(5.5)$ & $(5.6)$ \\
\hline & {$[0.0003]$} & {$[0.001]$} & [0.000] & & & \\
\hline Observations & 95 & 95 & 95 & 100 & 100 & 100 \\
\hline R-squared & & & & 0.530 & 0.563 & 0.565 \\
\hline
\end{tabular}

See Table 1 for variable details. Models 5.1-5.3 are estimated using two-step efficient GMM with the spatial lag of Epidemics (incidences), Epidemics (affected), and Epidemics (deaths) (all averaged of the previous ten years, 1990-1999), as instruments; Models 5.4-5.6 are estimated using OLS. Robust standard errors are in parentheses, and probability values are in brackets

Asterisks denote the following significance levels: $* * * p<0.01, * * p<0.05$, and $* p<0.1$

is the inverse distance defined as $\frac{1}{d_{i j}}$, where $d_{i j}$ represents the geographic haversine distance (in kilometers) between country $i$ and country $j$. The inverse distance weights countries closer in geographic distance greater than countries more distant. This gives us three instruments for each of the endogenous epidemic variables. These variables satisfy the two conditions for good instruments in that epidemics (in the previous decade) in neighboring countries do not directly impact own country entrepreneurship, and epidemics are highly correlated to epidemics in neighboring countries.

The results are reported in Models 5.1-5.3 of Table 5. Similar to the previous robustness results, the coefficients on the epidemics variables are larger in magnitude and display greater statistical significance. The diagnostic tests all agree that the instruments are both relevant and valid. The rejection of the null for the weak and underidentification tests confirm that the instruments are relevant, and the insignificance of the Hansen $\mathrm{J}$ test statistic for the overidentification test confirms that the instruments are valid (see Baum et al. 2007 for details). While the results for the control variables are somewhat mixed, the findings that epidemics, both frequency and severity, promote entrepreneurship are validated. Overall, these results confirm the validity of our baseline results that epidemics encourage entrepreneurship.

\section{Robustness Check 4: Accounting for Possible Nonlinearities}

The rejection of the null for the Ramsey RESET test shown at the bottom of Table 2 suggests the omission of possible nonlinearities. Therefore, as an additional robustness check, we augment the baseline models with a quadratic term for each of the epidemic variables and re-estimate the models.

These results are reported in Models 5.4-5.6 of Table 5. The coefficient on the linear term is positive and statistically significant in all models consistent with our main findings; however, the coefficient on the quadratic term is negative in all cases, but statistically insignificant for Epidemics (incidences). These results support the main findings; however, they also reveal that the relationship between epidemics and entrepreneurship is nonlinear with an upside down " $U$ " shape. The results for 
the remainder of the control variables are consistent with our earlier findings. Upon further inspection of the estimated nonlinearity, it is revealed that potential outliers may be driving this result, thus providing further evidence to support the analysis in "Robustness Check 2: Correcting for the Possible Influence of Outliers" section that accounts for these potential outliers.

\section{Conclusion}

This paper examines the unique and underexplored relationship between infectious disease epidemics and entrepreneurship. Moreover, we look at both the frequency and severity (i.e., number of affected and number of deaths) of diseases epidemics and their disproportionate impacts on entrepreneurship.

Using data on approximately 100 countries and employing different estimation techniques, the results suggest that disease epidemics are positively associated with entrepreneurial activity, and this is the case for both the incidence of epidemics and their severity, captured by the number of people affected and number of deaths. Quantitatively speaking, a 10 percent increase in epidemic incidences increases the entrepreneurship rate by 1.8 percent, while a 10 percent increase in the number of affected (deaths) caused by epidemics increases the entrepreneurship rate by 1.3 (0.7) percent. These results are robust after we account for alternate measures of entrepreneurship, additional factors, simultaneity, outliers, and nonlinearities.

The current coronavirus pandemic, as well as previous epidemics and pandemics, creates unique challenges. Entrepreneurs are thus an important force in a market economy to combat deadly and infectious diseases. It is often argued that it is government's role to mitigate the impact of negative externalities, yet in the case of disease epidemics the role of entrepreneurship may prove to be fruitful. As discussed earlier, there are countless examples of where entrepreneurs have solved important problems caused by the current pandemic-for instance, entrepreneurs safely fulfill the demand for certain unavailable goods/services (e.g., disinfectants, sanitizers, etc.). Given the onset of an epidemic, the entrepreneurial role is to mobilize resources to where they are most valuable, while also innovating to eliminate or reduce the spread of deadly diseases.

It is imperative to note that the positive relationship between epidemics and entrepreneurship reported in this paper does not of course suggest that epidemics be manufactured as a way to spur entrepreneurs, but rather biological disasters cause entrepreneurs to spring into action to mobilize resources to where there are most highly valued and to invent products and processes that help to prevent or mitigate the spread of infectious and deadly diseases. Entrepreneurs are therefore important for innovation that contains or prevents diseases before they become of epidemic or pandemic proportions.

As such, entrepreneurs serve an important function in a market economy during times of crises. Countries would benefit from policies that utilize the creatively and foresight of entrepreneurs. For instance, nations would benefit from enacting policies that support economic freedom, through such things as eliminating burdensome 
regulations, in order to encourage entrepreneurial entry into various industries. These steps would enable entrepreneurs to come up with creative ways to contain/ eliminate the incidence and diffusion of disease epidemics.

While this research is not meant to be the final word on the relationship between epidemics and entrepreneurship, we hope that we at least pushed the envelope a little further and with more and better data, future research can take a more refined look at this relationship. For example, it would be important to understand how epidemics influence entrepreneurial behavior and attitudes. One could argue that disease epidemics are stimulating entrepreneurial activity out of necessity rather than out of innovation, which might have differentiated influence on long-run growth and development. Consequently, it would be interesting to look at disaggregated results for both entrepreneurship (e.g., distinguishing between opportunity and necessitydriven entrepreneurship or nascent and established entrepreneurs) and epidemics (e.g., distinguishing between epidemics, pandemics, and endemics). Furthermore, focusing on microlevel data would be useful to parse out specific channels through which epidemics impact entrepreneurship. Lastly, it would be interesting to study entrepreneurialism within established businesses that pivot their business to satisfy certain demand.

\section{Appendix}

Table 6 List of countries

\begin{tabular}{llll}
\hline Algeria & Ecuador & Lebanon* & Senegal \\
\hline Angola & Egypt, Arab Rep. & Libya & Serbia \\
Argentina & El Salvador & Lithuania & Singapore \\
Armenia & Estonia & Luxembourg & Slovak Republic \\
Australia & Ethiopia & Madagascar & Slovenia \\
Austria & Finland & Malawi & South Africa \\
Bangladesh & France & Malaysia & Spain \\
Barbados & Georgia & Mexico & Sudan \\
Belarus & Germany & Montenegro & Suriname \\
Belgium & Ghana & Morocco & Sweden \\
Belize & Greece & Namibia & Switzerland \\
Bolivia* & Guatemala & Netherlands & Syrian Arab Republic* \\
Bosnia and Herzegovina & Hong Kong SAR, China* & New Zealand & Taiwan* \\
Botswana & Hungary & Nigeria & Thailand \\
Brazil & Iceland & North Macedonia & Tonga \\
Bulgaria & India & Norway & Trinidad and Tobago* \\
Burkina Faso & Indonesia & Oman & Tunisia \\
\hline & & &
\end{tabular}


Table 6 continued

\begin{tabular}{llll}
\hline Algeria & Ecuador & Lebanon* & Senegal \\
\hline Cameroon & Iran, Islamic Rep. & Pakistan & Turkey* \\
Canada & Ireland & Panama & Uganda \\
Chile & Israel & Peru & United Arab Emirates* \\
China & Italy & Philippines & United Kingdom \\
Colombia & Jamaica & Poland & United States \\
Costa Rica & Japan* & Portugal & Uruguay \\
Croatia & Jordan & Puerto Rico* & Vanuatu \\
Cyprus & Kazakhstan & Qatar & Venezuela, RB \\
Czech Republic & Korea, Rep. & Romania & Vietnam \\
Denmark & Kosovo* & Russian Federation & Yemen, Rep.* \\
Dominican Republic & Latvia & Saudi Arabia & Zambia \\
\hline
\end{tabular}

$\mathrm{N}=112$ countries

*Denotes countries not in the analysis when controls are included

Acknowledgements The authors acknowledge support from the University of Kentucky's Institute for the Study of Free Enterprise Summer Research Grant. We thank the editors and two anonymous referees for their valuable comments and suggestions.

\section{References}

Amorós, J., M. Guerrero, and E. Naranjo-Priego. 2020. COVID-19 Impacts on Entrepreneurship: Chile and Mexico. In Diagnosing COVID-19 Impacts on Entrepreneurship, ed. A. Ionescu-Somers and A. TarnawaLondon: London Business School.

Baldwin, R., and B. Weder di Mauro (eds.). 2020. Economics in the Time of COVID-19. London: CEPR Press.

Barro, R. J., Ursúa, J. F. and Weng, J., 2020. The Coronavirus and the Great Influenza Epidemic: Lessons from the "Spanish Flu" for the Coronavirus's Potential Effects on Mortality and Economic Activity. National Bureau of Economic Research Working Paper \# 26866.

Bartik, A.W., M. Bertrand, Z. Cullen, E.L. Glaeser, M. Luca, and C. Stanton. 2020. The Impact of COVID-19 on Small Business Outcomes and Expectations. Proceedings of the National Academy of Sciences 117(30): 17656-17666.

Basco, S., Domenech, J., and Roses, J. R. 2020. The Redistributive Effects of Pandemics: Evidence of the Spanish Flu. The London School of Economics and Political Science, Economic History Working Papers No: 308.

Baum, C.F., M.E. Schaffer, and S. Stillman. 2007. Enhanced Routines for Instrumental Variables/Generalized Method of Moments Estimation and Testing. The Stata Journal 7(4): 465-506.

Beach, B., Clay, K., Saavedra, M. H., 2020. The 1918 Influenza Pandemic and its Lessons for COVID-19. National Bureau of Economic Research Working Paper \#27673.

Becker, C. M., 1990. The demo-economic impact of the AIDS pandemic in sub-Saharan Africa. World Development 18(12): 1599-1619.

Béland, L.-P., Brodeur, A., Wright, T., 2020. The Short-Term Economic Consequences of COVID19: Exposure to Disease, Remote Work and Government Response. IZA Discussion Paper No. 13159.

Berggren, N., and T. Nilsson. 2015. Globalization and the Transmission of Social Values: The Case of Tolerance. Journal of Comparative Economics 43(2): 371-389. 
Bergh, A., and T. Nilsson. 2014. Is Globalization Reducing Absolute Poverty? World Development 62: 42-61.

Bjørnskov, C., and N.J. Foss. 2008. Economic Freedom and Entrepreneurial Activity: Some Crosscountry Evidence. Public Choice 134(3-4): 307-328.

Bloom, D.E., and A.S. Mahal. 1997. Does the Aids Epidemic Threaten Economic Growth? Journal of Econometrics 77(1): 105-124.

Bosma, N., and M. Hart. 2020. COVID-19 Impacts on Entrepreneurship: United Kingdom. In Diagnosing COVID-19 Impacts on Entrepreneurship, ed. A. Ionescu-Somers and A. TarnawaLondon: London Business School.

Boudreaux, C.J., M.P. Escaleras, and M. Skidmore. 2019. Natural Disasters and Entrepreneurship Activity. Economics Letters 182: 82-85.

Cardwell, R., and P.L. Ghazalian. 2020. COVID-19 and International Food Assistance: Policy proposals to keep food flowing. World Development 135: 1-4.

Cebula, R.J., C. Hall, F.G. Mixon Jr., and J.E. Payne (eds.). 2015. Economic Behavior, Economic Freedom, and Entrepreneurship. Cheltenham: Edward Elgar Publishing.

Chambers, D., and J. Munemo. 2019. Regulations, Institutional Quality and Entrepreneurship. Journal of Regulatory Economics 55(1): 46-66.

Coibion, O., Gorodnichenko, Y., and Weber, M. 2020. Labor Markets During the COVID-19 Crisis: A Preliminary View. National Bureau of Economic Research Working Paper \# 27017.

Correia, S., Luck, S., and Verner, E. 2020. Pandemics Depress the Economy, Public Health Interventions Do Not: Evidence from the 1918 Flu. Working Paper.

D’Adda, D., I. López, and D. Iacobucci. 2020. COVID-19 Impacts on Entrepreneurship: Italy and Spain. In Diagnosing COVID-19 Impacts on Entrepreneurship, ed. A. Ionescu-Somers and A. TarnawaLondon: London Business School.

Dahl, C.M., C.W. Hansen, and P.S. Jensen. 2020. The 1918 Epidemic and a V-shaped Recession: Evidence from Municipal Income Data. COVID Economics 6: 137-162.

Elert, N., and M. Henrekson. 2016. Evasive Entrepreneurship. Small Business Economics 47(1): 95-113.

Fairlie, R. 2020. The Impact of COVID-19 on Small Business Owners: Evidence from the First 3 Months After Widespread Social-distancing Restrictions. Journal of Economics \& Management Strategy 29(4): 727-740.

Galletta, S., and Giommoni, T. 2020. The Effect of the 1918 Influenza Pandemic on Income Inequality: Evidence from Italy. Working Paper.

Geloso, V., and Pavlik, J. B. 2020. Economic freedom and the economic consequences of the 1918 pandemic. Contemporary Economic Policy, forthcoming.

Goel, R.K., and J.W. Saunoris. 2019. International Corruption and Its Impacts Across Entrepreneurship Types. Managerial and Decision Economics 40(5): 475-487.

Guelich, U., and N. Takahashi. 2020. COVID-19 Impacts on Entrepreneurship: Japan and Thailand. In Diagnosing COVID-19 Impacts on Entrepreneurship, ed. A. Ionescu-Somers and A. TarnawaLondon: London Business School.

Hamilton, L. C. 1992. How Robust is Robust Regression? Stata Technical Bulletin 1(2).

Hayek, F.A. 1945. The Use of Knowledge in Society. American Economic Review 35(4): 519-530.

Jordá, O., Singh, S. R., and Taylor, A. M. 2020. Longer-run economic consequences of pandemics. National Bureau of Economic Research Working Paper \#26934.

Josty, P., M. Pauley, C. Saunders, G. Gregson, S. Schillo, H. Johnstone, et al. 2020. COVID-19 Impacts on Entrepreneurship: Canada. In Diagnosing COVID-19 Impacts on Entrepreneurship, ed. A. Ionescu-Somers and A. TarnawaLondon: London Business School.

Kahn, M.E. 2005. The Death Toll from Natural Disasters: The Role of Income, Geography, and Institutions. The Review of Economics and Statistics 87(2): 271-284.

Kelley, D., and F. Wright. 2020. COVID-19 Impacts on Entrepreneurship: United States. In Diagnosing COVID-19 Impacts on Entrepreneurship, ed. A. Ionescu-Somers and A. TarnawaLondon: London Business School.

Kirzner, I.M. 1997. Entrepreneurial Discovery and the Competitive Market Process: An Austrian Approach. Journal of Economic Literature 35(1): 60-85.

Koellinger, P.D., and A.R. Thurik. 2012. Entrepreneurship and the Business Cycle. The Review of Economics and Statistics 94(4): 1143-1156.

Mishra, K., and J. Rampal. 2020. The COVID-19 Pandemic and Food Insecurity: A Viewpoint on India. World Development 135: 1-3. 
Nordhagen, S., U. Igbeka, H. Rowlands, R.S. Shine, E. Heneghan, and J. Tench. 2021. COVID-19 and Small Enterprises in the Food Supply Chain: Early Impacts and Implications for Longer-Term Food System Resilience in Low- and Middle-Income Countries. World Development 141: 1-9.

Noy, I. 2009. The Macroeconomic Consequences of Disasters. Journal of Development Economics 88(2): 221-231.

Parker, S.C. 2018. The Economics of Entrepreneurship. Cambridge: Cambridge University Press.

Raddatz, C. 2007. Are External Shocks Responsible for the Instability of Output in Low-Income Countries? Journal of Development Economics 84(1): 155-187.

Ratten, V. 2020. Coronavirus Disease (COVID-19) and Sport Entrepreneurship. International Journal of Entrepreneurial Behavior \& Research 26(6): 1379-1388.

Sarasvathy, S. D., Dew, N., Velamuri, R., Venkataraman, S., 2003. Three Views of Entrepreneurial Opportunity. In Z. J. Acs and D. B. Audretsch (Eds.), Handbook of Entrepreneurship Research, pp. $141-160$.

Saunoris, J.W., and A. Sajny. 2017. Entrepreneurship and Economic Freedom: Cross-Country Evidence from Formal and Informal Sectors. Entrepreneurship \& Regional Development 29(3-4): 292-316.

Schumpeter, J.A. 1942. Capitalism, Socialism, and Democracy. London: Harper Perennial.

Thurik, A.R., M.A. Carree, A. Van Stel, and D.B. Audretsch. 2008. Does Self-employment Reduce Unemployment? Journal of Business Venturing 23: 673-686.

World Bank. 2020. World Development Indicators. Washington, DC: The Word Bank.

Yu, L., P.F. Orazem, and R.W. Jolly. 2014. Entrepreneurship Over the Business Cycle. Economics Letters 122(2): 105-110.

Yu, Z., Y. Xiao, and Y. Li. 2020. The Response of the Labor Force Participation Rate to an Epidemic: Evidence from a Cross-Country Analysis. Emerging Markets Finance and Trade 56(10): 2390-2407.

Publisher's Note Springer Nature remains neutral with regard to jurisdictional claims in published maps and institutional affiliations. 